\title{
J. M. W. Turner and the Construction of Scotland's Dual Scottish/British Identity
}

J. M. W. Turner et la construction de la double identité, écossaise et britannique, de l'Écosse

Lauren Brancaz-McCartan

\section{(2) OpenEdition}

\section{Journals}

Electronic version

URL: http://journals.openedition.org/etudesecossaises/1376

ISSN: 1969-6337

\section{Publisher}

UGA Éditions/Université Grenoble Alpes

Printed version

ISBN: 978-2-37747-047-1

ISSN: $1240-1439$

Electronic reference

Lauren Brancaz-McCartan, « J. M. W. Turner and the Construction of Scotland's Dual Scottish/British Identity », Études écossaises [Online], 20 | 2018, Online since 01 April 2018, connection on 08

September 2020. URL : http://journals.openedition.org/etudesecossaises/1376

\section{This text was automatically generated on 8 September 2020}

(c) Études écossaises 


\title{
J. M. W. Turner and the Construction of Scotland's Dual Scottish/British Identity
}

\author{
J. M. W. Turner et la construction de la double identité, écossaise et britannique, \\ de l'Écosse
}

Lauren Brancaz-McCartan

\section{Introduction}

In August 1822, over a year after his coronation as the king of the United Kingdom of Great Britain and Ireland and of Hanover, George IV spent sixteen days in Scotland to become acquainted with his Scottish subjects. His journey to Scotland was part of "a tour of the Celtic provinces" which the king had started in 1821 in Ireland, and which was meant to reconnect him with the different parts of his kingdom (Duncan, 2007, p. 5). It was the first time since the Jacobite rebellions that the ruling British monarch had come to Scotland. George IV's agenda included a number of appearances among the masses-upon his landing at Leith, at a grand procession taking him from Holyrood to Edinburgh Castle and showcasing the Scottish regalia, at a religious service in the High Kirk of Edinburgh, St. Giles, and at a theatre performance of Sir Walter Scott's Rob Roy (Mudie, 1822, pp. 86-8, 189-200, 243-9, 270-8). During his stay in Edinburgh, the King also repeatedly met with the upper levels of Scottish society, whose behaviour in front of the monarch had been strictly codified ahead of the pageant.

2 For the occasion, Sir Walter Scott had anonymously published a pamphlet entitled Hints Addressed to the Inhabitants of Edinburgh, and Others, in Prospect of His Majesty's Visit, which determined the way the Scottish upper class should be introduced to the king, the way men and women should be dressed at events, and even the number of feathers-"at least nine"-that ladies should wear in their head-dresses (An Old Citizen, 1822, p. 24). Scott's Hints were not a guidebook on what subjects should expect from the king-it was a manual on etiquette and decorum explaining what the Scots should do to become 
part of a historic event that would be discussed and recalled by future generations: "For, let it be observed, this is not an ordinary show-it is not all on one side. It is not enough that we should see the King; but the King must also see us" (ibid., p. 22). Such a record was meant for posterity, and it fitted with plans to develop a collective memory shared between the Scots and their monarch.

Therefore, George IV's stay in Edinburgh can, to some extent, be interpreted as a " mythomoteur", namely "a constitutive political myth" (Smith, 1988a, p. 58) which brought Scotland closer to the United Kingdom. Based on Anthony Smith's theories of ethno-nationalism, we will explore the construction of Scotland's dual identity in 1822, an identity celebrating the 1707 Acts of Union and loyalty to the British crown, while emphasising the distinctiveness of Scotland from England. Since Smith insists on nations' dependence on a system of "myths, memories, symbols and values" (ibid., p. 3), this paper will more specifically analyse pictorial representations of Scotland's dual British and Scottish identity in the 1820s. One of the artists who produced the greatest number of works related to the King's Jaunt was English painter Joseph Mallord William Turner, who was then working as an illustrator for a new edition of Sir Walter Scott's Provincial Antiquities and Picturesque Scenery of Scotland. Considering that Turner was in the employment of the main organiser of the royal visit, the two men can arguably be viewed as embodying the partnership that Scotland and England were forming in the early nineteenth century. That is why a selection of Turner's creations for the 1822 event will be analysed.

\section{George IV's visit as a mythomoteur celebrating Scotland's "unionist-nationalism"}

4 Anthony Smith distinguishes between two types of mythomoteur: "dynastic mythomoteurs", which centre on the ruling classes, and "communal mythomoteurs", which focus on whole communities (Smith, 1998a, pp. 57-68). George IV's visit to Edinburgh in 1822 appears to have been of the former type because it heavily insisted on the symbolism attached to the presence of the British monarch in Scotland. As Smith argues:

Dynastic mythomoteurs are, of course, political in intent, if not in form. [...] [T]heir prime purpose is political propaganda: to legitimate the deeds of the ruler and his house and pave the way for a smooth succession, perhaps in response to some internal challenge or external threat. (Ibid., p. 60)

That was precisely the aim of the 1822 pageant, which was designed to present George IV as Scotland's legitimate king and to bring greater social and political cohesion among the Scots and between Scotland and England.

By 1822, Scotland and England had been part of Great Britain for over a century, but they had not merged into a united community. The 1707 Acts of Union had provided for the dissolution of the Scottish Parliament and the incorporation of the Scots into the British state, but Scotland had been allowed to maintain the autonomy of its Church, the Kirk, and to keep its own educational and legal systems ("Articles of Union", n. d.). Moreover, the beginnings of the parliamentary Union between England and Scotland had been marred by Jacobitism, as the heirs of the defeated Catholic king, James VII of Scotland and II of England, who were partly supported by the Highlanders, had repeatedly tried to win the throne back from their dynastic rivals, the House of 
Hanover. The Act of Proscription after the defeat of the Jacobites at the Battle of Culloden in 1746 had aimed at suppressing revolts in the Highlands and at assimilating their inhabitants into Great Britain, but the subsequent Clearances had contributed to heightening the Highlanders' sense of grievance against Britain (Prebble, 1989, p. 33).

Additionally, two years before the visit of George IV, Scotland had had to fight a Radical War at home. A wave of strikes and social unrest had been started by a section of the Scottish labouring class who wanted to overthrow the government and put an end to recession, hard working conditions, poverty, and lack of political representativeness (ibid., pp.10-12). The radicals had been quickly defeated by the British government, and order had been restored, but the crisis had underlined the fact that the Scots were divided amongst themselves and from the rest of Britain by the early nineteenth century. The organisation of King George's visit could thus be interpreted as a " response to some internal challenge or external threat" (Smith, 1988a, p. 60).

7 In the 1810s, Sir Walter Scott had tried to construct a sense of the Scots as forming an ethnic community, "formed through symbolism, depicting ancestry, history, common culture and solidarity, along with a common name" (Smith, 1988b, p. 9), by encouraging sympathy for Gaelic culture in the form of picturesque and romanticised images of Scotland. Scott had also attempted to alleviate tensions between Scotland and England. In Waverley, for instance, Scott had focused on the imaginative identification of the eponymous hero with the Jacobites, and he had acknowledged the values of loyalty and honour which the Highlanders displayed, even when he had ceased to believe in their cause. The dramatisation of the conquest of the Highlands, seen through the eyes of an Englishman, suggested that the defeat of Jacobitism was necessary for the development of Scotland into a member of the Union (Scott, 2007).

8 Similarly, the baronet had endeavoured in 1818 to revive Scottish patriotism by launching a successful mission to find the crown, the scepter, and the sword which had first been used for the coronation of Mary Queen of Scots as an infant in 1543, and which had been locked away in Edinburgh Castle since the 1707 Union (Scott, 1839, pp. 14, 30-5). Scott had put "the sacred and venerable symbols" of Scotland's former independence into the limelight (Mudie, 1822, p. 199) not only to enhance Scotland's distinct identity and history, but also to emphasise the country's status as "an integral part of the British empire, by a union which gave new splendour to the throne, and a rapid increase of prosperity to the people" (ibid., p.157). Nevertheless, Scott's publications and the recovery of the Scottish regalia had lacked the direct personal authority of royalty, hence why some form of social and political cohesion could only be achieved thanks to the physical presence of George IV in Scotland in 1822. As a consequence, the King's Jaunt could be viewed as a political climax in bringing Scotland and England closer together, as a mythomoteur asserting Scotland's distinct identity as a fully-fledged partner of the Union.

George IV was the first British monarch to visit Scotland peacefully since the Glorious Revolution, over a hundred and thirty years earlier (ibid., pp. 5-6). His role was to physically symbolise the political partnership into which Scotland and England had entered in 1707: "What stronger proof could be given of the real union of the two kingdoms?" (Ibid., p.65) Furthermore, as the chief organiser of the visit, Scott highlighted the common ethnic roots that Scotland and England shared with each other. The baronet retraced George IV's origins-albeit wrongly-back to past Scottish kings: "The blood of the heroic Robert Bruce-the blood of the noble, the enlightened, 
the generous James I is in his veins." (An Old Citizen, 1822, pp. 6-7) As a Hanoverian king, George IV had no blood link with Scotland's last ruling dynasty, the Stuarts, but this imagined tie suggesting "a smooth succession" (Smith, 1988a, p. 60) between two competing royal families encouraged the Scots to view themselves as part of a British family headed by the king. The royal visit thus created a mythical link binding the Scots to their adoptive father, George IV, and to their enlarged family, Britain. Scott more specifically evoked the clan unit, the basis of Highland society up until the mideighteenth century, to appeal to the Scots, or at least part of them: "In short, we are THE CLAN, and our King is THE CHIEF." (An Old Citizen, 1822, pp. 6-7) The King's Jaunt can therefore be regarded as illustrating the "peculiar claims about the group's origins and lines of descent" which Anthony Smith identifies as "provid[ing] the focus of a community's identity and its mythomoteur, or constitutive political myth" (Smith, 1988a, pp. 57-8).

In 1822, the Scots exhibited signs of what Smith calls "a dual attachment":

[...] on the one hand, loyalty to the political unit, the state, expressed in terms of citizenship rights and obligations; on the other hand, a sense of affiliation and solidarity with the ethnic community into which one's family was born and socialized. (Ibid., p. 151)

The royal pageant capitalised on the image of Scotland as an ethnic community which Scott had contributed to constructing before 1822. At the same time, it was also crucial to the awakening of Scotland's loyalty to Britain, a loyalty which could be directly pledged to George IV in person. Thus, the King's Jaunt was instrumental in the shaping of Scotland's "unionist-nationalism", to use an expression coined by Graeme Morton in the early 1990 s to refer to "a Scottish nationalism which celebrated the parliamentary Union of 1707" (Morton, 1993, p. III). Admittedly, Morton applied the concept of "unionist-nationalism" to "the state/civil society relationship in the 1830-1860 period" (ibid., p. VIII), but this paper will demonstrate, in its subsequent analysis of Joseph Mallord William Turner's representations of the royal visit, that the seeds of unionistnationalism may have been planted as early as 1822 .

\section{Turner's representations of Scotland's dual identity on the occasion of George IV's visit}

11 Turner recorded the royal visit in two sketchbooks, the King's Visit to Edinburgh sketchbook and the King at Edinburgh sketchbook (Finley, 1981, p. 25). His ambitious project, which Gerald Finley called Turner's "Royal Progress" compositions (ibid., p. 26), only yielded three watercolours and four oil paintings in the end, but they give us an insight into the building of political and cultural relationships between Scotland and England in the first half of the nineteenth century.

12 Two of Turner's creations were published as monochrome grey watercolour and pencil compositions, which were used as frontispieces to the 1826 bound edition of Scott's Provincial Antiquities. In contrast, Turner's third watercolour entitled Edinburgh: March of the Highlanders was painted for Fisher's Illustrations to the Waverley Novels in 1836-7, but it was inspired by the 1822 pageant. Meanwhile, Turner's oil paintings include George IV at the Provost's Banquet in the Parliament House, George IV at St Giles's, Edinburgh, George IV's Departure from the 'Royal George', and Shipping, two of which-the latter two-were left in a highly unfinished state. Four of Turner's productions will be explored in this article. 
13 of the regalia of Scotland to Edinburgh Castle on Thursday, 22 August 1822. George IV appeared at the top of the castle, in pouring rain, to greet the Scots: "The King remained on this elevated situation a considerable time, cheered by the amazing multitude who occupied the Castle-Hill." (Mudie, 1822, p. 201) As one of Scotland's former royal residences, Edinburgh Castle was one of the key places of the 1822 visit. In Turner's vignette, the Scottish regalia is not represented, which can imply that Scotland's royal emblems are embodied by George IV as the king of the United Kingdom. Likewise, the British monarch himself cannot be distinguished, which suggests that he has merged with the crowd and that the Scottish population has adopted him as the rightful descendant of the Stuarts (Ardill, December 2012a). The Scottish regalia and the presence of George IV in Scotland are expected to be conjured up together since Scott's Provincial Antiquities includes a whole essay devoted to the origins and the rediscovery of Scotland's former symbols of monarchy (Scott, 1834, pp. 298-348). Turner's frontispiece is therefore meant to symbolise the union between the king-the head of the British state-and its northern kingdom and people-Scotland and the Scots. Arguably, the vignette gives visual support to the lineage that Scott sketched out in his Hints Addressed to the Inhabitants of Edinburgh, a lineage linking George IV to the former kings and queens of Scotland, and fusing them with the House of Hanover, the ruling British monarchy. the Latin motto of the Order of the Thistle, "Nemo me impune lacesset" (no one will harm me unpunished), a thistle, the Lion Rampant, a set of bagpipes, a sword, a claymore, and a sporran. They all express Scotland's pride in its distinct heritage, a heritage strongly associated with Scotland's former monarchy, the Highlands, and Jacobitism, which Sir Walter Scott had revived in his historical novels and turned into acceptable relics of Scotland's past which could be celebrated culturally. At the same time, however, the sword pointing to the right and the ascension of the crowd to the top of the castle could both suggest that Turner, like Scott, viewed Scotland as evolving and looking forwards, as though he wanted his vignette to be oriented towards the future, a future embodied by the figure of the king.

15 As a consequence, Turner's illustration appears to be exemplifying Anthony Smith's concept of "dual orientation-to political future and cultural past"-which lies at the heart of "the creation of nations in the modern world" (Smith, 1988a, p. 152). This vignette showcases Scotland's distinct cultural heritage through its historical emblems and symbols, but it also focuses on the 1707 political union between England and Scotland, which was given new impetus and credibility in 1822 through the personal involvement of King George IV. Turner thus depicted Scotland's early-nineteenthcentury identity as dual because it celebrated "unionist-nationalism" (Morton, 1993, p. III).

The frontispiece to volume two of Provincial Antiquities, known as The Arrival of the King at Leith Harbour (The Mission of Sir Walter Scott), represents, as the title indicates, the arrival of King George IV in Leith Harbour on 14 August on board of the Royal George. It also includes three small boats approaching the king's barge on the left, one of which carried Sir Walter Scott: “What!' said his Majesty, 'Sir Walter Scott? the man in Scotland I most wish to see! Let him come up"' (Mudie, 1822, p. 88) Below the boats, two hands are clasping each other. These can be interpreted as Sir Walter Scott's and 
George IV's since the two men met on the royal barge (Ardill, December 2012b). On a symbolic level, the two hands can be construed as standing for the 1707 Acts of Union between Scotland and England, and the renewal of that political alliance in 1822 thanks to the personal presence of the monarch in Edinburgh. The clasped hands are positioned on the same level, which implies a balanced partnership between Scotland and England. They are placed in the centre of the vignette, and are highlighted by a sunrise in the background, which hints at the potentially promising future associated with the renewal of the Union. They also appear to be emerging from smoke, which, in religious ceremonies, symbolises the immortal soul. As a result, the union between England and Scotland is portrayed as long-lasting in this watercolour.

Scotland's distinctiveness is expressed through Edinburgh Castle and Arthur's Seat, drawn in the background, and through the tartan sleeve revealing Sir Walter Scott's hand on the right. Admittedly, the baronet's erroneous fusion of Highland and Lowland traditions was harshly criticised at the time as "tartan mania" and as "humbug and masquerade" which were "childishly, helplessly unworthy of Scotland" (Blackwood's Edinburgh Magazine, 1822, p. 354). Nevertheless, the King's Jaunt enabled the Scots to regard themselves as forming a people with their own characteristics, which would be contested and challenged over the following two decades, but which clearly differentiated Scotland culturally from the rest of Britain. In comparison, Turner also conveyed Scotland's unionism and loyalty to the British monarchy through what Ardill identified as George IV's emblem, a white horse and a star, and through the royal motto "Dieu et mon droit", which was originally adopted by English, not Scottish, monarchs (Burke \& Burke, 1842, p. 4). The rays of sunshine linking the allusion to God at the top of the vignette and the two hands at the bottom seem to be giving the renewal of the Union a divine sanction.

Therefore, just as with the vignette published as a frontispiece to volume one of Provinvial Antiquities, "two kinds of 'myth-symbol complex' and two sets of allegiances (the so-called 'dual loyalties') [appear to be] operat[ing]: one public and political with its official symbolism [...], and one semi-private and cultural for each ethnic community" (Smith, 1988a, p.151). Once again, Turner represented the sense of "unionist-nationalism" (Morton, 1993, p. III) that Scotland experienced during the visit of King George IV to Edinburgh.

In contrast, Turner's painting entitled George IV at St Giles's, Edinburgh commemorates a major historic event since the English and the Scottish Reformations, namely the attendance of George IV, an Anglican king, at a Presbyterian service at St Giles's on 25 August 1822 (Mudie, 1822, p. 243). Turner painted the monarch under a canopy at the back of the church, standing on a raised platform which dominates the assembly. The Presbyterian minister is given more prominence than the king himself, since the former is placed in the foreground and since his presence is underlined by the bright star-shaped ceiling of the pulpit in which he preaches. This picture stresses another characteristic which distinguishes Scotland from the rest of Britain-the independence of the Kirk and the fact that the British monarch has no authority over it.

On the one hand, George IV was arguably depicted as a simple parishioner respectful of Presbyterianism, who seemed to have been accepted by the Scots as one of their own. On the other hand, however, Turner left a number of hints pointing up the superior status of George IV. The king forms the tip of a triangle whose sides are delineated by the group on the right-hand side standing behind the tartan-clad boy who pinched his 
hand in the door of a pew, by the two elegantly-dressed ladies whispering to each other at the front, and by the woman wearing a black shawl over her head in the middle of the assembly. Turner also implied another triangle, whose tip is formed by the top window from which sunshine pours over the assembly and which radiates across the king's canopy as far as the bottom right corner of the painting. The two other sides of that triangle are formed by the shadow converging to the minister's pulpit, and by the dark line running along the white wall of the cathedral. In those two triangles, two women leaning against the pews by a massive pillar are turning round to catch a glimpse of the monarch, which further sets the king into relief. The two triangles seem to indicate that George IV connects the Scots together, and that his role as the monarch of two countries is illuminated by light coming from above. It is therefore sanctioned by God.

Consequently, Turner once again blended the cultural specificities of Scotland-since the scene takes place in the seat of Presbyterianism-with the political status of the British monarch as the head of Scotland. The English painter merged the two main characteristics of Anthony Smith's concept of "dual attachment"-"loyalty to the political unit, the state"-in the figure of George IV, and "a sense of affiliation and solidarity with the ethnic community" with the participation of the British monarch in a typically Scottish religious ritual (Smith, 1988a, p. 151).

In his oil painting representing George IV at the Provost's Banquet in the Parliament House, Edinburgh, Turner made a similar use of perspective to emphasise the dual nature of Scotland's identity as part of the UK and as a distinct region of that kingdom ("Joseph Mallord William Turner, George IV at the Provost's Banquet in the Parliament House", 2017). Turner drew the monarch under a canopy of state, whose vibrant red and gold colours enhance his status as the king of Scotland. George IV occupies the right-hand quarter of the painting, and his body, placed directly under the canopy, seems to form a vertical line to which another line converges. The latter comes from a bright source of light in the middle left of the picture, which runs across the table to the monarch himself. That second line links George IV to

[...] 295 persons, [...] all the noblemen and many of the gentlemen of distinction then in Edinburgh ; the officers of state ; the judges of the different courts, the law officers of the crown; and a great number of naval and military officers. (Mudie, 1822, p. 228)

These people came to attend the banquet organised by the city of Edinburgh. As such, those two lines connecting the British monarch with the people of Scotland, represented by its highest officials, can be construed as exemplifying the legal and political link which was forged between Scotland and England with the 1707 Acts of Union, and which was embodied by George IV in 1822 on his visit to Edinburgh.

Additionally, Turner was careful to celebrate Scotland's cultural uniqueness, since he depicted a ceremony orchestrated by Sir Walter Scott to point out the blood linkhowever fraudulent-existing between the Scots and their Hanoverian monarch. George IV at the Provost's Banquet illustrates the washing of the royal hands in "a silver basin, containing rose-water [...] by William Howison Craufurd" (Mudie, 1822, p. 232), the laird of Braehead in Midlothian, in commemoration of the day when Craufurd's ancestor rescued "[o]ne of the kings of Scotland, James the $2 \mathrm{~d}$ or $3 \mathrm{~d}$ " from "a gang of gypsies", and washed the monarch's wounds with water (Mudie, 1822, p. 232, footnote). In Turner's painting, the two converging lines which were just mentioned draw the eye of the spectator to a group of men kneeling before George IV-Craufurd among them- 
as though their presence was just as important as the king's. The monarch's gaze, turned towards the basin held out to him, appears to confirm that idea. In so doing, Turner underscored the-erroneous-kinship existing between George IV and the Stuart dynasty. The exact identity of the king of Scotland to whom that story relates was deliberately left vague-"James the $2 \mathrm{~d}$ or $3 \mathrm{~d}$ "-as though it did not matter as much as the cultural connection that was established between the ancient Scottish monarchy and the House of Hanover.

Again, Turner highlighted the "dual orientation-to political future and cultural past" which characterised Scotland in the early nineteenth century (Smith, 1988a, p. 152). In John Morrison's words, "[t]he remarkable degree to which the artist [Turner] absorbed and endorsed Scott's construction of the nation and the king reflects perhaps the extent to which the loyalist but singular identity caught the contemporary imagination" (Morrison, 2003, p. 55). As partners in the publication of a new edition of Provincial Antiquities, Scott and Turner collaborated with each other in the 1820s in shaping Scotland's unionist-nationalism. They celebrated Scotland's political integration within the Union as a distinct cultural entity.

\section{Conclusion}

In 1822, Scotland emerged as a fully-fledged nation incorporated into the United Kingdom, not a nation in Ernest Gellner's or Benedict Anderson's sense because there was no desire to (re)establish a separate Scottish state, but a nation in Anthony Smith's sense. Indeed, the King's Jaunt drew upon myths and references to Scotland's past which had already been disseminated through Sir Walter Scott's novels and the rediscovery of the Scottish regalia in 1818, and which had constructed a sense of Scotland as a distinct ethnic community. Scotland's identity was mobilised in 1822 and given new political impetus on the occasion of George IV's visit to Edinburgh. As Smith argued, " $[t]$ his is because the constituents of these identities and cultures-the myths, memories, symbols and values-can often be adapted to new circumstances by being accorded new meanings and new functions" (Smith, 1988a, p. 3). In 1822, Scotland's identity was re-assessed and re-constructed as dual-Scottish because it celebrated Scotland's cultural specificities and British because it asserted Scotland's loyalty to the British monarch.

This paper only focused on evidence from the works of Joseph Mallord William Turner based on one specific event which has often been dismissed as "a garish travesty-[...] a bogus, retro-Jacobite, Highland pageantry" (Duncan, 2007, p. 4). Nevertheless, John Morrison has proven that Scotland's dual identity in the nineteenth century was

[...] not merely the stuff of manufactured pageantry. Beyond the theatre of events such as George IV's visit to Edinburgh [...], unionist-nationalism was how Scots represented themselves to each other. It was how Scots talked about Scottishness. Thus artists from Alexander Nasmyth [...] to John Duncan found no difficulty in expressing their identity in terms of both Scotland and Britain. (Morrison, 2003, p. 8) Scottish painters such as Sir David Wilkie, Alexander Carse, James Skene, and to some extent Alexander Nasmyth, all tend to suggest that unionist-nationalism was 
acknowledged as a viable national sentiment that could be embraced by the Scots in the first half of the nineteenth century.

By way of illustration, this phenomenon was visually portrayed by Alexander Carse in George IV Landing at Leith ("George IV Landing at Leith", 2017). The king emerges in the foreground from a throng of people, whose positions on the left, right, and back of the painting seem to form two massive arms welcoming the monarch, as though the people of Scotland were accepting George IV as their rightful head of state. Yet at the same time, the king does not disappear in the midst of that crowd because the latter is carefully arranged into an outer circle of civilians and an inner circle of civil and military officials who make room in front of the monarch and thus highlight his presence. Such a layout is meant to reflect the obedience and loyalty of the Scots to George IV, the embodiment of the royal standard of the United Kingdom in front of which he stands. In turn, the monarch acknowledges the cultural diversity of his people, symbolised by the few tartan sashes that appear here and there amongst the crowd and by the flying of the Saltire.

Scotland's duality in the 1820s was not the mere figment of Scott's and Turner's imagination. As Morrison asserts, "[p]owerful as he was, Scott was in no position to force a system of beliefs on anyone. Rather, his construction was recognised as articulating a widely shared set of beliefs about Scotland" (Morrison, 2003, p. 12). As a consequence, the King's Jaunt which Scott contributed to organising in 1822, and in which Turner as well as other English and Scottish painters took part, can arguably be viewed as forming the mythomoteur which allowed Scotland to voice its unionistnationalism throughout most of the nineteenth century.

\section{BIBLIOGRAPHY}

ANDERSON Benedict, 1983, Imagined Communities, London, Verso.

AN OLD CITIZEN [Sir Walter Scott], 1822, Hints Addressed to the Inhabitants of Edinburgh, And Others, In Prospect of His Majesty's Visit, Edinburgh, William Blackwood, Waugh and Innes, and John Robertson.

ARDILL Thomas, December 2012a, "Frontispiece to Volume One of the Provincial Antiquities and Picturesque Scenery of Scotland c. 1822-5 by Joseph Mallord William Turner", Tate. Available on $<$ www.tate.org.uk/art/artworks/turner-frontispiece-to-volume-one-of-the-provincialantiquities-and-picturesque-scenery-of-d13748> (consulted March 2018).

ARDILL Thomas, December 2012b, "Frontispiece to Volume Two of the Provincial Antiquities and Picturesque Scenery of Scotland c. 1822- 5 by Joseph Mallord William Turner", Tate. Available on $<$ www.tate.org.uk/art/artworks/turner-frontispiece-to-volume-two-of-the-provincialantiquities-and-picturesque-scenery-of-d13749> (consulted March 2018).

“Articles of Union”, The UK Parliament, n. d. Available on <www.parliament.uk/documents/ heritage/articlesofunion.pdf> (consulted June 2017). 
Blackwood's Edinburgh Magazine, September 1822, vol. 12, no. 68.

BURKE John \& BURKE John Bernard, 1842, A General Armory of England, Scotland, and Ireland, London, Edward Churton.

DunCAN Ian, 2007, Scott's Shadow, Princeton, Princeton University Press.

FINLEY Gerald, 1981, Turner and George the Fourth in Edinburgh, Edinburgh, The Tate Gallery and Edinburgh University Press.

GELLNER Ernest, 1964, Thought and Change, London, Orion.

“George IV Landing at Leith”, Art UK, 2017. Available on <https://artuk.org/discover/artworks/ george-iv-landing-at-leith-1822-93153> (consulted June 2017).

“Joseph Mallord William Turner, George IV at St Giles's, Edinburgh, c. 1822”, Tate, 2017. Available on <www.tate.org.uk/art/artworks/turner-george-iv-at-st-giless-edinburgh-n02857> (consulted June 2017).

“Joseph Mallord William Turner, George IV at the Provost's Banquet in the Parliament House, Edinburgh, c. 1822", Tate, 2017. Available on <www.tate.org.uk/art/artworks/turner-george-ivat-the-provosts-banquet-in-the-parliament-house-edinburgh-n02858> (consulted June 2017).

MORRISON John, 2003, Painting the Nation: Identity and Nationalism in Scottish Painting, 1800-1920, Edinburgh, Edinburgh University Press.

MORTON Graeme, 1993, Unionist-Nationalism: The Historical Construction of Scottish National Identity, Edinburgh 1830-1860, PhD thesis, Edinburgh, University of Edinburgh.

MUDIE Robert, 1822, A Historical Account of His Majesty's Visit to Scotland, Edinburgh, Oliver and Boyd.

PREBBLE John, 1989, The King's Jaunt: George IV in Scotland, August 1822, London, Fontana.

ScoTT Walter (Sir), 1834, Provincial Antiquities, Edinburgh, Robert Cadell.

ScотT Walter (Sir), 1839, Description of the Regalia of Scotland, Edinburgh, Neill.

ScoтT Walter (Sir), 2007, Waverley, Edinburgh, Edinburgh University Press.

SMITH Anthony D., 1988a, The Ethnic Origins of Nations, Oxford, Blackwell.

SMITH Anthony D., 1988b, “The Myth of the 'Modern Nation' and the Myths of Nation”, Ethnic and Racial Studies, vol. 11, no. 1, pp. 1-26.

\section{ABSTRACTS}

This article will analyse to what extent the two weeks that George IV spent in Edinburgh in 1822 can be viewed as a "mythomoteur" (Smith, 1988a, p. 58), namely "a constitutive political myth" which triggered the construction of Scotland's dual Scottish/British identity after the defeat of Jacobitism and the collapse of the Radical War. Such duality, celebrating both Scotland's distinctiveness and its loyalty to the British crown, will be examined through four of the works which English painter Joseph Mallord William Turner produced on the occasion of the royal visit, when he was working for Sir Walter Scott as an illustrator of a new edition of Provincial Antiquities.

Cet article analysera dans quelle mesure le séjour de deux semaines que George IV a effectué à Édimbourg en 1822 peut être interprété comme un «mythomoteur» (Smith, 1988a, p. 58), à savoir 
un « mythe politique constitutif » qui a entraîné la construction de la double identité de l'Écosse, une identité écossaise et britannique, suite à la défaite du jacobitisme et à la répression de l'Insurrection écossaise de 1820. Cette dualité, célébrant à la fois le caractère distinctif de l'Écosse et sa loyauté envers la couronne britannique, sera examinée à partir de quatre œuvres produites par le peintre anglais Joseph Mallord William Turner à l'occasion de la visite royale, alors qu'il travaillait pour Sir Walter Scott comme illustrateur d'une nouvelle édition de Provincial Antiquities.

\section{INDEX}

Mots-clés: George IV, J. M. W. Turner, Sir Walter Scott, mythomoteur, nationalisme unioniste Keywords: George IV, J. M. W. Turner, Sir Walter Scott, mythomoteur, unionist-nationalism

\section{AUTHOR}

\section{LAUREN BRANCAZ-MCCARTAN}

Université Savoie Mont Blanc.

Lauren Anne-Killian Brancaz was jointly awarded her Ph.D. by the University of Aberdeen and the École doctorale de Grenoble in late 2014. She has been working as an agrégée teaching and research fellow (ATER) at the Université Savoie Mont Blanc since September 2015, where she has mostly been teaching British and Irish history at undergraduate level. Her research interests include pan-Celticism, relationships between states and nations, diaspora movements, and collective memories.

Lauren Anne-Killian Brancaz a obtenu une thèse en co-tutelle de l'université d'Aberdeen et de l'École doctorale de Grenoble fin 2014. Agrégée, elle a travaillé en tant qu'ATER à l'Université Savoie Mont Blanc à partir de septembre 2015, où elle a enseigné essentiellement la civilisation britannique et irlandaise au niveau licence. Ses champs de recherche sont, entre autres, le panceltisme, la relation entre État et nation, les mouvements de diaspora et la notion de mémoire collective. 